\title{
Letters
}

To the Editors:

I welcome Professor Calixto Machado's interesting article in the October, 2010 issue of MEDICC Review (Describing Life to Define Death: A Cuban Perspective) and concur with his definition of death as the irreversible loss of consciousness, involving all parts of the brain, a definition he has defended with convincing scientific arguments in his book Brain Death: A Reappraisal, which I recently reviewed.[1] His article is highly relevant, since certification of death is an indispensable prerequisite for post-mortem retrieval of organs or tissues.

I would like to emphasize that in Cuba, Article 83 of Decree No. 139 (1988), a health legislation regulation, stipulates that any medical procedure related to transplantation of organs or tissues may be performed only after certification of donor death, as required by law and according to strict diagnostic criteria, based on methods and procedures established by the Ministry of Public Health.[2] These are precisely as summarized by Dr Machado in his Viewpoint.

In addition, in Cuba, a citizen's official identity card has a section permitting an individual to freely indicate whether, upon death, he or she wishes to be an organ donor.

As Dr Machado points out, the use of a ministerial resolution rather than an act of parliament to determine all aspects related to certification of death facilitates reassessment informed by future scientific advances. Thus, the legal framework can be modified according to research results from Cuba and elsewhere that contribute to scientific understanding of death and diagnosis of brain death-a polemical discussion that historically has undergone many important changes and surely will continue to do so.

Ricardo Hodelín Tablada MD PhD

Neurosurgeon, Saturnino Lora Provincial Teaching Hospital Santiago de Cuba

1. Hodelín Tablada R. Muerte encefálica. Un nuevo enfoque. MEDISAN. 2011;15(2):280-3. [Spanish]

2. República de Cuba. Gaceta oficial. Decreto No. 139 del 4 de febrero de 1988 (Reglamento de la Ley de Salud). Edición ordinaria No. 12. La Habana, lunes 22 de febrero de 1988:177-192. [Spanish]

\section{Author Calixto Machado Responds}

I thank Dr Hodelín, one of Cuba's experts on brain death, for his comments on my views and their medical, legal, and ethical implications.

In contrast to the old Spanish Civil Code, which defined death as "irreversible cessation of cardiorespiratory functions," the lawyers who drafted Cuba's current Code took an advanced position in the global context when they wrote: "The determination and certification of death is to be made by duly authorized experts in conformity with regulations established by the competent authority."[1] Early in the 1990s, the Ministry of Public Health proposed establishment of a National Commission on Death Certification; and after several drafts, on September 21, 2001, Public Health Resolution 90 was published in the Republic of Cuba's Official Gazette, providing the definitive response to the Civil Code's requirements for determining and certifying death in Cuba.

In general, the aspects of this Resolution that can be considered novel, nationally and internationally, are included in my Viewpoint. The clinical and instrumental signs for determining death are attached as appendices to the Resolution, to be reviewed periodically by the National Commission on Death Certification, as scientific and technological advances warrant.[2] Thus, as pointed out, the Resolution enabled development of a regulatory framework for determining death sufficiently flexible to permit review and amendment with scientific and technological progress.

1. Gaceta Oficial de la República de Cuba. Justicia. Ley N. ${ }^{\circ} 59$ del 16 de Julio de 1987 (Código Civil). Ciudad de La Habana: Ministerio de Justicia. Edición Extraordinaria N. ${ }^{\circ}$ 9, 16-7-1987; p. 39-81. Spanish.

2. Machado C. Comisión Nacional para la Determinación y Certificación de la Muerte. Resolución para la determinación y certificación de la muerte en Cuba. Rev Neurol. 2003;36:763-70. Spanish. 